\title{
ZATRZYMANE W KADRZE HISTORII. REPORTAŻE SYLWII SIEDLECKIEJ O BUŁGARII
}

\author{
Adriana KovacheVA \\ Adam Mickiewicz University in Poznan
}

\begin{abstract}
CAPTURED IN THE FOCUS OF HISTORY. SYLWIA SIEDLECKA'S REPORTAGES ON BUL-
GARIA. The article analyses Polish writer Sylwia Siedlecka's collection of reportages entitled Ztote piachy (Golden Dusts) against the background of other modes of writing about Bulgaria, developed within the last decade. The comparison outlines the particular positioning of Siedlecka's reportages as texts in which the cultural dichotomy East - West loses its importance. The weakening of those categories is achieved not only on the conceptual level of the book, but also by the author's affective writing style. The demythologization of Bulgaria's imaginary geography leads to a more stable embedding of the presented facts and events on the timeline of the country's history. Siedlecka's reportages, based on the biographies of the characters depicted in them, may be perceived as elements of a greater story about the problematic existence of the People's Republic of Bulgaria.
\end{abstract}

Keywords: reportage, Sylwia Siedlecka, People's Republic of Bulgaria, imagined geographies, affect

Pierwsze profesjonalne reportaże o Bułgarii w języku polskim powstają na początku XX wieku. Od tego czasu pojawiają się i kształtują różne sposoby opowiadania o tym kraju, choć nie składają się one na piśmiennictwo o pokaźnych rozmiarach. Tą tematyką zajmują się pisarze i dziennikarze o różnych przekonaniach i poglądach - od Tadeusza Stanisława Grabowskiego poczynając, na Lesławie Bartelskim i Wilhelmie Machu kończąc. XXI wiek przynosi zdecydowany odwrót zarówno od tradycji rozwijających się przed II wojną światową, jak i od tendencji powojennych. Celem niniejszego szkicu jest wskazanie i omówienie kolejnej zmiany w piśmiennictwie reportażowym, która dokonała się za sprawą opublikowanego w 2019 roku tomu Złote piachy. Zbioru reportaży Sylwii Siedleckiej nie da się przyporządkować do żadnego z wypracowanych w ostatniej dekadzie sposobów pisania o Bułgarii. Choć autorka odwiedza różne zakątki kraju (wyjeżdża do jego południowych krańców - do miejscowości Rupite koło Petriczu, gdzie żyła i pracowała jasnowidzka Wanga; wybiera się w góry - dociera do szczytu Buzłudża, żeby odwiedzić opuszczony Dom-Pomnik Bułgarskiej Partii Komunistycznej), jej opowieść nie przyciąga czytelników obietnicą przygody, 
składaną mimochodem lub wprost przez reportażystów-podróżników ${ }^{1}$. O wiele ważniejsze niż pokonywanie przestrzeni geograficznych jest tu podróżowanie w czasie. Świadczy o tym wybór przedstawionych postaci - każda z nich, choć większość to osoby na wskroś nowoczesne, obeznane z globalizującym się światem, jest nawiedzana przez duchy przeszłości. Autorka pokazuje, jak przez współczesność prześwituje minione, jej bohaterowie interesują ją nie tylko jako praktycy codzienności, lecz przede wszystkim jako przewodnicy po historii.

Siedlecka nie ma również na celu stworzenia kulturoznawczego studium bułgarskiej mentalności, wyjaśniającego i przybliżającego lokalne zwyczaje i zachowania. Taka strategia wymagałaby translatorskiej aktywności i zaangażowania w przetworzenie obcej tkanki kulturowej na zrozumiały dla polskich odbiorców, czytelny tekst ${ }^{2}$, autorka jednak z niej rezygnuje. Dostarcza bogatych informacji o kraju i praktykach zamieszkujących go ludzi - bezdyskusyjnie jej książka ma ogromny walor poznawczy, ale cały wysiłek składania tych informacji w spójną interpretacyjną całość Siedlecka zostawia czytelnikom. Reportażystka nie moralizuje ani nie wartościuje - tworzy przestrzeń dla różnych punktów widzenia oraz systemów aksjologicznych, pokazuje też wiele możliwości wyjaśnienia i zrozumienia. W tekście o Ludmile Żiwkowej, córce wieloletniego przywódcy Ludowej Republiki Bułgarii Todora Żiwkowa, pisarka odnotowuje nieprzejrzystość tej postaci:

Drobna, trójkątna twarz zostaje tysiąc razy powiększona na zdjęciach, które zawisną w urzędach, salach obrad, na stadionach piłkarskich i w szkołach. Ale nawet jeśli powiększyć to zdjęcie milion razy, uchwycona na nim twarz niewiele nam ujawni, a kiedy powiększymy jeszcze bardziej, obraz zmienia się w grube ziarno. A więc oddalmy się znów, a zobaczymy osobę, która spogląda nie w obiektyw, tylko gdzieś w bok. Może częściowo przyczyną jest wada wzroku, a może to, że twarz nie chce dostosować się do tego, co narzuca jej oko fotografa, chcące widzieć bułgarską księżniczkę, wielką spadkobierczynię familii, która rządzi Bułgarią. Mojemu spojrzeniu Ludmiła stawia opór, rozpada się na wiele różnych opowieści. (Siedlecka 2019:37)

Zmiana perspektyw oglądu, dawanie świadectwa wielorakości i różnorodności opowiadanego świata - ta koncepcja pisania i myślenia o Bułgarii, streszczona w pierwszym reportażu, obowiązuje w całym zbiorze. Naprzemienne zbliżanie się i oddalanie spojrzenia reporterskiego przekłada się na specyficzny sposób przedstawiania opisywanego świata.

1 Reportażystami-podróżnikami są poeta Artur Nowaczewski i blogerka Ania Jackowska. Ich sposób pisania nie tworzy wspólnej płaszczyzny porównawczej, więc nie chodzi tu o zestawienie stylu czy formy tekstów. Hostel Nomadów (Nowaczewski 2017) i Samotnie przez Bałkany (Jackowska 2011) należą do tej samej kategorii, ponieważ są to dzienniki podróży, a główną rolę konstrukcyjną w nich pełni autentycznie doznawana wędrówka.

2 W taką praktykę są zaangażowane autorki książek W bałkańskim kociołku. Opowieść o Bułgarii (Iliev 2019) oraz Njama problem! Bułgarska przygoda (Gajecka 2020). 
Siedlecka nieraz kreuje portrety psychologiczne, zmusza do podglądania intymnych przestrzeni swoich bohaterów (wtedy jej opisy wibrują liryzmem i groteską), żeby chwilę później usytuować ich prywatność w szerszym społecznym i politycznym kontekście. Ta technika widzenia odróżnia reportaże ze Złotych piachów od osobistego tonu relacji o Bułgarii z dopiero co kształtującego się nurtu reportaży genealogicznych, w których poznawanie kraju wiąże się z odkrywaniem własnej historii rodzinnej ${ }^{1}$. Skoro więc opowieść ta nie jest ani typowym travelogue ${ }^{2}$, ani typowym opisem etnograficzno-antropologicznym, a także obce są jej dylematy tożsamościowe, to warto zastanowić się nad tym, z jakiego stanowiska jest sformułowana i co mówi o Bułgarii. By móc odpowiedzieć na powyższe pytania, najpierw należy jednak sprawdzić, gdzie leży Bułgaria Siedleckiej³.

\section{W WIEDNIU, STAMBULE I MOSKWIE}

Geografia - jak przekonuje Przemysław Czapliński za Edwardem Saidem - jest pochodną postrzegania, a nie twardych danych i literatura nie tylko umie zwracać uwagę na to, jaką rolę odgrywa ona w naszym rozumieniu świata, lecz także ma moc negowania dotychczasowych map (Czaplinski 2016: 9-11). Narracja Siedleckiej nie angażuje się w analizę opowieści, dyktujących kształt geografii wyobrażonej Bułgarii, stara się też nie wpisywać sensów przestrzeni w siatkę znaczących relacji z mocarstwami, z którymi historia państwa była i jest sprzęgnięta. Odwrotnie - autorka kontestuje geograficzne określenia, nie tyle nazywające cechy faktyczne, ile opisujące dany rejon jako obszar mentalny, reprezentujący określone wartości kulturowe - jako system struktur społecznych, układ sit politycznych i ekonomicznych (Lebkowska 2019: 187).

Uciekając przed semantycznym determinizmem głównych kierunków świata: Wschód - Zachód, Północ - Południe, Siedlecka posługuje się kategorią Europy Środkowo-Wschodniej - czyni tak w reportażach o Ludmile Żiwkowej czy o obecnym premierze Bułgarii Bojko Borysowie i jego stosunku do uchodźców z Syrii. Te dwa przykłady sygnalizują niezgodę autorki na Kunderowską geografię Europy Środkowej ograniczonej do Polski,

1 Przedstawicielką tego nurtu jest Magdalena Genow, która w swojej książce błyskotliwe obserwacje o historii, codzienności, tradycjach i kulturze Bułgarii powiązała z dylematami wielokulturowości, dwujęzyczności i dorastania na styku kilku kultur (Genow 2019).

2 W polskiej tradycji gatunek ten ma dość niejasną charakterystykę i obejmuje zarówno dzienniki z podróży, rządzące się prawami poetyki dziennikowej (tj. fragmentaryczności, nieciągłości tematycznej, skupienia się na podmiocie wypowiedzi), jak i bardziej zdyscyplinowane formy pisarskie, na przykład szczególnie rozpowszechnione w dobie modernizmu listy czy notatki z podróży, listy-korespondencje, reportaże podróżnicze (Lebkowska 2019: 189).

3 Inspiracją do sformułowania tego pytania jest wielokrotnie tu przywoływana książka Przemysława Czaplińskiego Poruszona mapa (Czaplinski 2016). 
Czech i Węgier (Kundera 1984). Jednocześnie trudno doszukać się w tekście przyzwolenia na rozszerzoną formułę Andrzeja Stasiuka, którego Europa Środkowa sięga aż po Bałkany (Stasiuk \& Andruchowycz 200o, Stasiuk 2004). Bałkańskość to kategoria pojawiająca się w Złotych piachach jeszcze rzadziej (głównie jako charakterystyka praktyk codzienności, na przykład w kontekście opisu fenomenu muzycznego czałga, odpowiednika jugosłowiańskiego turbofolku i rumuńskiej maneli) - choć, jak przekonuje reportażystka, zdecydowanie wyraźniej dostrzec ją można w orientalnym pochodzeniu wielu zwyczajów, przejawiającym się na przykład w nazewnictwie. W reportażu o przymusowej zmianie nazwisk mieszkających w Bułgarii Turków, która nastąpiła w latach 1984-1985 i została określona przez władzę mianem procesu odrodzeniowego, autorka pisze:

Pięćset lat życia w imperium osmańskim pozostawiło w języku bułgarskim wiele tureckich słów, których nie sposób po prostu wymazać ani zaprzeczyć ich istnieniu. Do takiego stopnia zrosły się z bułgarszczyzną, że nie ma na nie bułgarskich odpowiedników, bo często przedmioty, które oznaczają, powstały albo zostały zaadaptowane z innych kultur w czasie, kiedy Bułgaria znajdowała się pod panowaniem Osmanów. [...] Czadyr, czarszaf, czekmedże. Parasol, prześcieradło, szuflada. Dżudże, czyli krasnoludek, ale również karzeł. I piękno słowo łale, które znaczy tulipan. (Siedlecka 2019: 87)

Siedlecka jednak nie orientalizuje Bułgarii. Jej narracja, budowana po Saidzie i po lekcjach teorii postkolonialnych, wystrzega się tego łatwego stereotypu ${ }^{1}$, a ewentualne spiętrzenie spostrzeżeń, które mogą świadczyć o takim podejściu, tworzy jedynie mylny punkt orientacyjny.

W zbiorze Złote piachy kategorie geograficzne są osłabione co najmniej na cztery sposoby. Po pierwsze, poprzez uświadamianie ich historycznej zmienności za pomocą gestu ułożenia mapy geograficznej na osi czasu. Jeśli więc Europa Środkowo-Wschodnia, to jest to Europa Środkowo-Wschodnia bardzo ściśle zakorzeniona w okresie rządów komunistycznych lub określona w nomenklaturze Unii Europejskiej. Jeśli Orient, to tylko w jego konkretnym wcieleniu Imperium Osmańskiego, a nie jako metonimia Wschodu. Drugi sposób, w jaki narracja reporterska wychodzi poza stereotypową semantykę kategorii geograficznych, wiąże się z przywiązaniem do konkretnej nazwy, bardzo często odzwierciedlającej historię lokalną. Siedlecka rezygnuje z głównych kierunków i wprowadza miejscowe koordynaty: od Sofii po Złote Piaski (Siedlecka 2019: 32); wylicza: Ruse, Kyrdżali,

1 Orientalizacja Bułgarii jest jednak wciąż strategią marketingową przyjmowaną przez wydawców wspomnianych wcześniej reportaży i dzienników podróży. Prawie we wszystkich materiałach informacyjnych pojawiają się informacje o kraju, który przez ponad pięć wieków znajdował się w granicach Imperium Osmańskiego, który jest wciąż tajemniczy i nieznany, który uwodzi mało uczęszczanymi szlakami. 
Warna, Płowdiw, Stara Zagora, Burgas (s. 111); odwraca hierarchie ważności: Działały bodaj cztery tureckie teatry, w tym jeden w Razgradzie, nieopodal Sewar (s. 75); śledząc historyczne zmiany toponimów, pokazuje, jaki wpływ na geografię ma władza: po czym opuścit Deliorman, czyli zgodnie z nowa nazwa Łudogorie (s. 73).

Kolejna strategia przeciwko kolonialnym prawidłowościom geografii wyobrażonej to organizacja narracji nie wokół konkretnych miejsc (choć każdy reportaż wiąże się z takim punktem na mapie), lecz wokół konkretnych biografii. Pomimo sugestywnych opisów Sofii, dzięki którym miasto staje się równoprawnym bohaterem większości reportaży, swoje fabuły Sylwia Siedlecka snuje na kanwie ludzkich życiorysów - córki dyktatora Ludmiły Żiwkowej, jasnowidzki Wangelii Pandewej Dimitrowej, architekta Georgiego Stoiłowa, poety Hasana Karahüseyinova i jego syna Mehmeta, który dokonał aktu samospalenia, filozofki, literaturoznawczyni i psychoanalityczki Julii Kristevej, artysty cyrkowego Aleksandra Bałkańskiego, dyrygentki Dory Christowej, premiera Bojka Borisowa itd.

Pęknięcia dychotomicznych podziałów geograficznych następują także za sprawą uważnego wpatrywania się w sprzeczności i niespójności, pojawiające się w przestrzeni miejskiej. Sofia jest terenem, który najczęściej staje się laboratorium tego ekscentrycznego patrzenia. Sylwia Siedlecka przekonuje, że stolica Bułgarii - miasto bez centrum, miasto-palimpsest - rozsadza każdą próbę jednoznacznego określenia jej geograficznej przynależności. Miasto pamięta nie tylko odległe czasy Traków i Rzymian, ale nosi na swoim ludnym ciele blizny niedalekiej przeszłości, kiedy totalitarnym władcom śniły się sny o podboju kosmosu. Idąc ulicami Sofii obok stawianych w okresie komunizmu budynków o monstrualnych rozmiarach, widzi się też odrestaurowane mury obronne dawnego miasta Serdika z II wieku, kamienice z początku XX wieku i nowe, ultranowoczesne ze swoimi szklanymi powłokami, wielopiętrowe centra biznesowe. Jak stwierdza autorka: $W$ trakcie jednego spaceru można się poczuć jak w Wiedniu, Stambule i Moskwie jednocześnie (Siedlecka 2019: 29). W kwestionowaniu utartych szlaków, oficjalnych przestrzeni i wielkich narracji kategorii geograficznych odzwierciedla się wybrana przez autorkę strategia naprzemiennego oglądu, zbliżania i oddalania się, zarysowywania możliwości: zamiast definiowania - szukanie wieloznaczności.

\section{DUCHY BUZŁUDŻY}

Dzięki wyjściu poza dychotomie Zachód - Wschód, Północ - Południe i rozluźnieniu sieci geograficznej w reportażach ze zbioru Złote piachy Bułgaria zostaje usytuowana stabilniej w czasowym układzie współrzędnych. Wydarzenia z okresu Bułgarskiej Republiki Ludowej tworzą bowiem retrospektywny horyzont dla wszystkich przejawów współczesnego życia społecznego i dla wszystkich biografii przedstawionych w tomie. Jest to kolejna 
odsłona naprzemiennego oglądu, choć tym razem nie zmienia się dystans między narratorką a przedstawionym fragmentem świata, lecz perspektywa historyczna. Teraźniejszość, opisywana w swojej sensualnej konkretności, staje się znakiem przeszłości. Historia nie tylko prześwituje przez ludzkie życia i współczesność - Bułgarzy nie mogą się od niej uwolnić, ich codzienność wciąż toczy się w cieniu BRL-u. Dziedzictwo totalitarne określa życie polityczne w kraju, o czym świadczy przedstawiony w reportażu Chłop z Bankji życiorys Bojka Borisowa, który zaczynał swoją karierę publiczną jako ochroniarz Żiwkowa. Co więcej - dziedzictwo to nadal ciąży także na intelektualistach, nie zdołali oni bowiem ani się z nim rozliczyć (zob. reportaż Sabina, stanowiący bricolage z fragmentów z teczki oraz z wypowiedzi, wywiadów i esejów Julii Kristevej), ani go dostatecznie dobrze zbadać, ani o nim opowiedzieć (zob. reportaż Buzłudża): W Bułgarii - twierdzi jedna z bohaterek, Dora Iwanowa, założycielka Fundacji Projekt Buzłudża - brakuje całościowego spojrzenia: nie ma muzeów komunizmu, w podręcznikach szkolnych brak prawdziwych informacji, a jeśli już sq, to skq̨e (Siedlecka 2019: 68).

Niedobór pamięci i praktyk pamiętania nie dziwią. Z jednej strony istnieje szereg wydarzeń lub - jak chce Georgi Gospodinow - niewydarzonych wydarzeń (Gospodinov 2008), o których Bułgarzy woleliby zapomnieć. Siedlecka je wylicza (i spis jest na pewno niepełny), odnotowuje także możliwe przyczyny posłuszeństwa społeczeństwa wobec władzy. Uczestnictwo wojsk Bułgarii w inwazji Układu Warszawskiego w Czechosłowacji, propozycja przyłączenia kraju do ZSRR, złożona przez Todora Żiwkowa Nikicie Chruszczowowi, brak drugiego obiegu, słabe rozluźnienie cenzury podczas odwilży w drugiej połowie lat 50., brak dysydentów - to tematy, które, choć wspomniane na marginesie, napomknięte, niesproblematyzowane jako zagadnienia polityczne, wpływają na życie przedstawionych w reportażach bohaterów, egzystujących w świecie zrujnowanej wspólnoty ludzkiej (Siedlecka 2019: 82). Z drugiej strony, autorka odnotowuje nastroje i tendencje przyczyniające się do ciągłego aktualizowania przeszłości. Siedlecka sugeruje, że istnieją dwie sfery organizujące wyobraźnię zbiorową Bułgarów będące szczególnie podatne na wpływy tradycji beerelowskiej - teokratyczny sposób postrzegania władzy oraz wiara, nasycona mistycyzmem i często odbiegająca od chrześcijańskiej ortodoksji. Autorka uważnie śledzi współzależności między skłonnością do przypisywania boskich przymiotów władcom a fatalizmem, których historyczne ślady odkrywa w paradoksalnej duchowości Ludmiły Żiwkowej, jawnie głoszonej i promowanej w ateistycznej komunistycznej Bułgarii, czy w sprawczości, jaką obdarzono jasnowidzkę Wangę, zatrudnioną na stanowisku doradczyni Żiwkowa i otaczaną kultem aż po dziś dzień: 
Wangi nie widać na bilbordach, ale jej mit żyje. Dba o to fundacja jej imienia, bardzo wpływowa, a jednocześnie tajemnicza, bo nie figuruje w oficjalnych rejestrach organizacji. [...] kompleks Wanga od momentu powstania jest jednym z najbardziej dochodowych ośrodków religijnych w kraju [...]. (Siedlecka 2019: 133)

Te dwie cechy bułgarskiego społeczeństwa zbliżają je do Wschodu, a według Siedleckiej ustawiają je także w szczególnej sytuacji wobec Rosji, a ściślej - wobec Związku Radzieckiego, z którym łączy się historia Bułgarskiej Republiki Ludowej. W reportażach ze zbioru Złote piachy Związek Radziecki urasta do siły nie tylko ustalającej standardy życia politycznego i gospodarczego, lecz także organizującej życie prywatne obywateli, włącznie z rozrywką i czasem wolnym. Nie ma przestrzeni ani prywatnej historii, która nie zostałaby przeniknięta przez wszechogarniającą władzę ZSRR-u. Władza ta jest wszędzie: od domów elity rządzącej (Ludmiła Żiwkowa być może zostaje zatruta na zlecenie KGB we własnej wannie), poprzez architekturę (Georgi Stoiłow studiuje w Moskwie i zdobytą tam wiedzę stosuje, projektując wszystkie swoje budynki, niezależnie od ich przeznaczenia, co więcej - czas nie wprowadza żadnych zmian w jego wyuczonym stosunku do architektury), aż po sposoby organizacji dni wolnych od pracy (obchody rocznic, promowanie kina i cyrku jako ulubionych dziedzin sztuki Lenina). Oznaki tej władzy są widoczne także w żywej tkance przestrzeni miejskiej, a autorka chętnie je zbiera i kataloguje:

Dla Georgiego centrum jest parę kroków od jego mieszkania, czyli przy soborze Aleksandra Newskiego, gigantycznej cerkwi, której nie sposób ominąć wzrokiem, bo jej kopuły błyszczą się w słońcu na złoto i jest ich tak dużo, jakby nocą rozmnażały się przez pączkowanie. Dzięki tej cerkwi Sofia przypomina rosyjskie miasto [...]. (Siedlecka 2019: 42)

Ludzie na co dzień niemający ze sobą żadnego kontaktu na ten jeden dzień tworzą demokratyczny tłum bogaczy i biednych, emerytów, bandziorów i studentów, i po wysokich schodach wchodzą do ozłoconej cerkwi Narodzenia Pańskiego zbudowanej tu przez Rosjan na pamiątkę wojny lat 1877-1878, w której udział wzięli też bułgarscy ochotnicy, żeby wesprzeć rosyjskie wojska przeciw tureckim. Ta cerkiew to pierwszy historyczny pomnik przyjaźni rosyjsko-bułgarskiej, otwarty w 1902 roku i do 2005 roku pozostający własnością Rosyjskiego Kościoła Prawosławnego. Można powiedzieć, że to odnowione cacko to jedna z wizytówek relacji rosyjsko-bułgarskich. (Siedlecka 2019: 65)

Jak się okazuje - na cień BRL-u nakłada się cień Rosji.

Przeciwstawienie Zachodu i Wschodu nie zostaje jednak sformułowane ani razu wprost przez autorkę. Pojawia się ono w wypowiedzi Ewgenija Bakyrdżiewa, który podjął decyzję zdetonowania mauzoleum Georgiego Dimitrowa, twierdząc, że: wystawienie na widok publiczny mumii pasuje bardziej do bolszewickiej, azjatyckiej tradycji, a nie do centrum europejskiego, chrześcijańskiego miasta, jakim jest Sofia (Siedlecka 2019: 156). Narracja Złotych piachów dyskredytuje podobne dychotomie i demitologizuje zarówno opowieść 
o narzuconej z zewnątrz władzy komunistycznej, jak i przekonanie, że wyjście z cienia własnej historii oznacza zwycięstwo kulturowej, ekonomicznej i politycznej opcji Zachodu.

\section{INTENSYWNOŚĆ PATRZENIA}

Poznawcza autonomiczność reportaży Sylwii Siedleckiej jest wypadkową etycznej i estetycznej postawy reporterki. Wrażliwość na różnorodne interpretacje świata łączy się tu z intensywnością pisarskiego spojrzenia i odczuwania. Narracja prowadzona jest przez podmiot poddający się działaniu zmysłowych jakości i wrażeń, tj. znaków materialnych, które - w odróżnieniu od znaków światowych i miłosnych jako jedyne są prawdomówne i ożywają jako odkryta przez konkretna jednostkę esencja (Deleuze 200o: 18). Opowiadany świat przeżywany jest cieleśnie, przenika przez skórę i nozdrza: Nad leczniczymi źródłami unosi się gorąca para, która zagęszcza powietrze i zostawia na mojej skórze niewidoczny wilgotny filtr (Siedlecka 2019: 111); W powietrzu Sali kinowej w Bojanie pachnie kurzem i rozgrzaną taśma filmową, a stary węgierski projektor głośno oddycha (Siedlecka 2019: 242). Jawi się w swoich szczegółach, budzi wstręt, migocze lub wytrąca z naturalnego doświadczenia kinestetycznego. Innymi słowy, świat ów zostaje uchwycony w ruchu i ważniejsze staje się nie to, jaki jest, a jak działa na podmiot mówiący. Wrażeniowa intensywność charakteryzuje nie tylko teksty zebrane w zbiorze Złote piachy, lecz w ogóle prozę Sylwii Siedleckiej, która jest autorką tomu opowiadań Szczeniaki (2010) i powieści Fosa (2015). Jej styl pisarski Maciej Robert określa jako kontaminację klarownej, bezdusznej wręcz opisowości z nieoczekiwanymi elementami poetyckimi (Robert 2015: 67). Marek Szladowski pisze zaś o wprawianiu czytelnika $w$ hipnotyzujq̨ce osłupienie, które często nie pozostawia czasu na ujawnienie się emocji (Szladowski 2011: 141). W Złotych piachach intensywność wrażeniowa oddziałuje także na strukturę tomu. Składa się on z samodzielnych wyrazistych i świetnie skomponowanych fragmentów, które łączą omawiane za każdym razem z innej perspektywy, powtarzające się wątki tematyczne. Zmysłowe postrzeganie świata narusza bowiem narracyjną ciągłość.

Co ciekawe, pomimo bardzo intensywnej pracy zmysłów, nie bierze w niej udziału smak $^{1}$. Bułgaria nie przekształca się tu w przedmiot do skonsumowania. Jest to bardzo znaczący gest odmowy uczestniczenia w procesach utowarowienia, gest o zasadniczym znaczeniu dla sposobu, w jaki reportażystka traktuje swoich rozmówców, informatorów i bohaterów. W reportażu o historii trzech pokoleń Karahüseyinovów - Ahmet, czyli Asparuch

1 Reportaże Krzysztofa Vargi o Węgrzech - Gulasz z turula (2008) i Czardasz z mangalica (2014) - są kontrapunktem tego znaczącego braku. O funkcjach narodowej kuchni i jej symboliki u Vargi zob. Czaplinski 2016: 290-293. 
- spotkaniom z członkami rodziny towarzyszy wspólne spożywanie posiłków czy słodyczy. Siedlecka jest lakoniczna i konkretna w opisie potraw, nie stają się one samodzielnym przedmiotem przedstawienia. Ważne są w swoim symbolicznym znaczeniu wymiany i jako znak ustalanej relacji. W opisywanych scenach narratorka jest równorzędną uczestniczką poczęstunków, ale dzieli się jedzeniem na zasadach określanych przez tubylców:

Młoda Şemsiye, która patrzy na mnie ze zdjęcia, ma czarną aureolę włosów wokół głowy, wyraziste, odznaczające się pod oliwkową skórą kości policzkowe i oczy, w których błyszczy ciekawość. Şemsiye, która siedzi naprzeciw mnie przy stoliku we włoskiej knajpce w centrum Sofii, jest od niej starsza o pół wieku, ale oczy ma takie same. Zamawia kieliszek białego wina i porcję tortu ze świeżymi figami. Odkraja kawałek ciasta ze swojego talerzyka i przekłada na mój. (Siedlecka 2019: 80) ${ }^{1}$

Etyka nie-przywłaszczania pozwala wyjść poza własne kulturowe przyzwyczajenia lub poznawcze stereotypy oraz umożliwia uczestnictwo bez uprzedzeń w procesie komunikacji i nawiązywania relacji. Taka jest właśnie etyczna postawa, jaką Siedlecka proponuje swoim czytelnikom - autorka pokazuje proces wchodzenia w relację, który stanowi zarazem proces odrzucenia władzy piszącego podmiotu. Reportażystka nie wie lepiej od swoich bohaterów, nie narzuca im swoich reguł poznawania i porządkowania świata, nie wikła ich w sieć własnych interpretacji zjawisk i faktów. Chce być z nimi w kontakcie, chce ich widzieć i słuchać. Pozostaje jej jednak władza wyboru, z kim wchodzi w relację i autorka tego wyboru dokonuje bardzo świadomie, nie roszcząc sobie prawa do tworzenia pełnego obrazu, do wyczerpującej opowieści. Odnotowuje wielość roztaczających się przed nią możliwości, wątków, problemów i tematów oraz konieczność ich zredukowania: Georgi ma trzydzieści kilka lat $i$ jest ubrany w błękitna, dopasowaną koszulę. Stawia przede mną czekoladki i każe się częstować. Nie wiem, którq wybrać z pięciu otwartych przede mna pudełek (Siedlecka 2019: 71).

Najczęściej z pola widzenia reporterskiego oka wyłączone zostają współczesne konflikty polityczne i bieżące życie kulturalne. Powracająca do teraźniejszości przeszłość przesłania problemy pokolenia, dla którego historia beerelowskiego państwa znaczy niewiele. Socjologiczne portrety mieszkańców Bułgarii umieszczone są w ściśle określonej ramie czasowej - między końcem II wojny światowej a momentem zapisu, ale globalizacja, płynność przepływu informacji i idei, przeniesienie relacji międzyludzkich do świata wirtualnego czy

1 Ta scena zasługuje na szczególną uwagę, ponieważ pokazuje, jak bardzo odmienna jest reporterska praktyka Siedleckiej od voyeuryzmu Krystyny Kurczab-Redlich (zob. Czaplinski 2016: 42-47). W tej scenie nie ma asymetrii spojrzenia. Nie tylko pisarka patrzy, lecz sama też jest obserwowana. Wyraźna staje się także rezygnacja z aparatu i robienia zdjęć, tj. z kontroli widzialnego świata. Siedlecka w odróżnieniu od Kurczab-Redlich nie używa swoich możliwości zapisu i utrwalania przeżyć w sposób, który ogranicza wolność lokalnych mieszkańców lub narusza ich godność. 
ponadnarodowe problemy klimatyczne zostają poza kadrem. Autorka jednak nie obiecuje, że będzie patrzeć w przyszłość. Tytuł książki jest pierwszym sygnałem, że opowieść Sylwii Siedleckiej to sprawozdanie z obecności w szczelinie między płytami tektonicznymi historii. Zbiór reportaży Złote piachy jest jedną z najlepszych książek nie tyle o współczesnej Bułgarii, ile o dekonstruowaniu stereotypów myślenia i pisania o Bułgarii, a także jedną z najlepiej opowiedzianych historii o długim trwaniu BRL-u.

\section{REFERENCES}

Czaplinski 2016: Czaplinski, Przemyslaw. The Shifted Map. Krakow: Wydawnictwo Literackie, 2016. [In Polish: Czapliński, Przemysław. Poruszona mapa. Wyobraźnia geograficzno-kulturowa polskiej literatury przełomu XX i XXI wieku. Kraków: Wydawnictwo Literackie, 2016.]

Deleuze 2ooo: Deleuze, Gilles. Proust and Signs (original title Proust et les signes). Transl. by Michal Pawel Markowski. Gdansk: słowo/obraz terytoria, 200o. [In Polish: Deleuze, Gilles. Proust i znaki. Tłum. Michał Paweł Markowski. Gdańsk: słowo/obraz terytoria, 200o.]

Gajecka 2020: Gajecka, Marta. No Problem! A Bulgarian Adventure. Warszawa: Po Godzinach, 2020. [In Polish: Gajęcka, Marta. Njama problem! Butgarska przygoda. Warszawa: Po Godzinach, 2020.]

Genow 2019: Genow, Magdalena. Bulgaria - Gold and Rakia. Poznan: Wydawnictwo Poznanskie, 2019. [In Polish: Genow, Magdalena. Bułgaria - złoto i rakija. Poznań: Wydawnictwo Poznańskie, 2019.]

Gospodinov 20o8: Gospodinov, Georgi. “1968 - Memories of a Year That Did Not Happen.” Liberalen Pregled (07.08.2008), accessed 30.09.2020. http://librev.com/index.php/discussion-bulgariapublisher/318-1968-. [In Bulgarian: Господинов, Георги. „1968 - спомени от една неслучила се година." Либерален преглед (7.08.2008), достъп: 30.09.2020. http://librev.com/index.php/ discussion-bulgaria-publisher/318-1968-.]

Iliev 2019: Iliev, Bozenna. In a Balkan Cauldron. A Story about Bulgaria. Pelplin: Bernardinum, 2019. [In Polish: Iliev, Bożenna. W bałkańskim kociołku. Opowieść o Bułgarii. Pelplin: Bernardinum, 2019.] Jackowska 2011: Jackowska, Anna. Alone through the Balkans. Warsaw: Pascal, 2011. [In Polish: Jackowska, Anna. Samotnie przez Batkany. Warszawa: Pascal, 2011.]

Kundera 1984: Kundera, Milan. “The Tragedy of Central Europe.” Zeszyty Literackie, no 5 (1984): 14-31. [In Polish: Kundera, Milan. „Zachód porwany albo tragedia Europy Środkowej.” Tłum. M. L. Zeszyty Literackie, no 5 (1984): 14-31.]

Lebkowska 2019: Lebkowska, Anna. "Europe Imagined in the Literature of the Modernist Era." In Lebkowska, A. Somatopoetics - Affects - Imagination. Literature of the XX and XXI Centuries: 187249. Krakow: Jagiellonian University Press, 2019. [In Polish: Łebkowska, Anna. „Europa wyobrażona w literaturze doby modernizmu." W: Łebkowska, A. Somatopoetyka - afekty - wyobrażenia. Literatura XX i XXI wieku: 187-249. Kraków: Wydawnictwo Uniwersytetu Jagiellońskiego, 2019.]

Nowaczewski 2017: Nowaczewski, Artur. Nomad Hostel. Warsaw: Iskry, 2017. [In Polish: Nowaczewski, Artur. Hostel Nomadów. Warszawa: Iskry, 2017.] 
Robert 2015: Robert, Maciej. “To Jump over the Moat.” Nowe Ksiazki, no 7 (1157 / 2015): 66-67. [In Polish: Robert, Maciej. "Przeskoczyć fosę." Nowe Książki, no 7 (1157 / 2015): 66-67.]

Siedlecka 2010: Siedlecka, Sylwia. Puppies. Warsaw: W.A.B., 2010. [In Polish: Siedlecka, Sylwia. Szczeniaki. Warszawa: W.A.B., 2010.]

Siedlecka 2015: Siedlecka, Sylwia. Moat. Warsaw: W.A.B., 2015. [In Polish: Siedlecka, Sylwia. Fosa. Warszawa: W.A.B., 2015.]

Siedlecka 2019: Siedlecka, Sylwia. Golden Dusts. Wolowiec: Czarne, 2019. [In Polish: Siedlecka, Sylwia. Złote piachy. Wołowiec: Czarne, 2019.]

Stasiuk 2004: Stasiuk, Andrzej. On the Road to Babadag. Wolowiec: Czarne, 2004. [In Polish: Stasiuk, Andrzej. Jadąc do Babadag. Wołowiec: Czarne, 2004.]

Stasiuk \& Andruchowycz 20oo: Stasiuk, Andrzej \& Jurij Andruchowycz. My Europe: Two Essays on So-Called Central Europe. Wolowiec: Czarne, 200o. [In Polish: Stasiuk, Andrzej \& Jurij Andruchowycz. Moja Europa. Dwa eseje o Europie zwanej Środkowq. Wołowiec: Czarne, 20oo.]

Szladowski 2011: Szladowski, Marek. "Casual Existences." Strony (Opole), no 3-4 (2011): 140-143. [In Polish: Szladowski, Marek. "Przygodne istnienia." Strony. Opolskie Czasopismo społecznokulturalne, no 3-4 (2011): 140-143.]

Varga 20o8: Varga, Krzysztof. Turul Goulash. Wolowiec: Czarne, 2008. [In Polish: Varga, Krzysztof. Gulasz z turula. Wołowiec: Czarne, 2008.]

Varga 2014: Varga, Krzysztof. Csardas with a Mangalica. Wolowiec: Czarne, 2014. [In Polish: Varga, Krzysztof. Czardasz z mangalica. Wołowiec: Czarne, 2014.] 